\section{A codon 129 polymorphism in the PRIP gene}

\author{
Frank Owen, Mark Poulter, John Collinge and \\ Tim J.Crow \\ Division of Psychiatry, Clinical Research Centre, \\ Watford Road, Middlesex HA1 3UJ, UK
}

Source/Description: The polymerase chain reaction (PCR) and allele specific oligonucleotide (ASO) hybridisation were used to detect a common polymorphism within the open reading frame (ORF) of the human prion protein (PRIP) gene. This polymorphism has previously been reported as a mutation (1). The oligonucleotide sequences for amplification of the ORF of the PRIP contained EcoRI and BamHI linkers respectively and were 5'-AAGAATTCTCTGACATTCTCCTCTTCA-3' ${ }^{\prime}$ and 5'-AAGGATCCCTCAAGCTGGAAAAAGA-3'. PCR mixtures $(100 \mu \mathrm{l})$ contained $1-2 \mu \mathrm{g}$ genomic DNA, $250 \mathrm{ng}$ of each primer and 2.5 units of Taq polymerase (Cetus) in the manufacturer's recommended buffer. Cycling conditions were: $95^{\circ} \mathrm{C}(1.5 \mathrm{~min})$, $50^{\circ} \mathrm{C}(1.5 \mathrm{~min}), 72^{\circ} \mathrm{C}$ ( $\left.3 \mathrm{~min}\right)$ for 35 cycles. ASO sequences were 5'-CGGCTACATGCTGGG-3' (Met $\left.{ }^{129}\right)$ and 5'-CGGCTACGTGCTGGG-3' (Val $\left.{ }^{129}\right)$. Prehybridization (3h) and hybridization (16h) were in $6 \times$ SSPE, $0.1 \%$ BLOTTO, $0.5 \%$ SDS, $1 \mathrm{mM}$ EDTA and $0.1 \mathrm{mg} / \mathrm{ml}$ denatured, sonicated, salmon sperm DNA at $35^{\circ} \mathrm{C}$. Membranes were washed once at $35^{\circ} \mathrm{C}$ (15 min) and twice at $46^{\circ} \mathrm{C}(15 \mathrm{~min})$ in $3 \mathrm{M}$ tetramethylammonium chloride, $50 \mathrm{~mm}$ Tris- $\mathrm{HCl}(\mathrm{pH} \mathrm{8.0)}, 2$ mM EDTA and $0.1 \%$ SDS.

Polymorphism: A single base substitution in codon 129 of the PRIP gene (ATG to GTG) results in an amino acid substitution of valine for methionine.

Frequency: Studied in 36 caucasians.

Met $^{129}$ Allele (A1): 0.68

$\mathrm{Val}^{129}$ Allele (A2): 0.32

Chromosomal Location: 20pter-p12.

Mendelian Inheritance: Codominant inheritance demonstrated in two families. An example is presented in Figure 1.

Other Comments: Mutations in the ORF of the PRIP gene have been reported in some but not all cases of the transmissible dementias (2). The codon 129 polymorphism, therefore, could prove useful in genetic linkage studies of those transmissible dementias where mutations in the ORF of the PRIP gene have not been identified.

References: 1) Goldfarb,L.G. et al. (1989) Am. J. Hum. Genet. 45 (Suppl. A189). 2) Goldgaber,D. et al. (1989) Exp. Neurol. 106, 204-206.

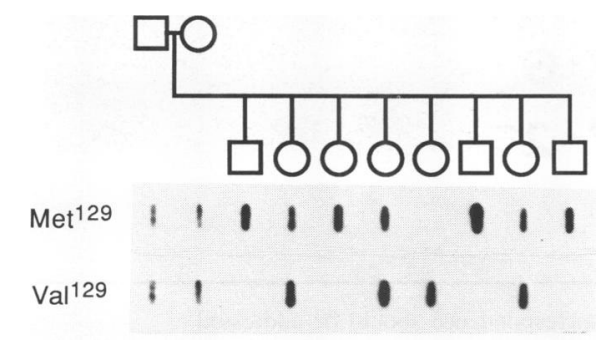

\section{RFLP for Mbol in the human tyrosinase (TYR) gene detected by PCR}

\author{
L.B.Giebel and R.A.Spritz \\ Laboratory of Genetics, University of Wisconsin, \\ Madison, WI 53706, USA
}

Polymerase Chain Reaction (PCR): Two 20mer oligonucleotides 5'-GCAAGTTTGGCTTTTGGGGA-3' (nucleotides 308-327) and 5'-CTGCCAAGAGGAGAAGAATG-3' (nucleotides $800-819$ ) derived from exon 1 of the human tyrosinase gene $(1,2)$ were used to amplify the corresponding gene fragments from genomic DNA $(0.1-1 \mu \mathrm{g})$ of the probands. Forty cycles of PCR were performed in $100 \mu \mathrm{l}$ volumes of $10 \mathrm{mM}$ Tris- $\mathrm{HCl}$ $\mathrm{pH} 8.3,50 \mathrm{mM} \mathrm{KCl}, 1.5 \mathrm{mM} \mathrm{MgCl} 2,200 \mu \mathrm{M}$ of each dNTP, $100 \mu \mathrm{g} / \mathrm{ml}$ gelatin, $1 \mu \mathrm{M}$ of each primer, and 2.5 units of Taq DNA polymerase (Perkin-Elmer Cetus, Norwalk, CT) using an automated thermal cycler (Coy Laboratory Products, Inc., Ann Arbor, MI). Each cycle consisted of 1.5 min each at 94, 50, and $72^{\circ} \mathrm{C}(3)$.

Polymorphism: MboI detects a two-allele polymorphism within codon 192 of the human tyrosinase gene, TCT (MboI site) versus TAT (no MboI site), resulting in a non-pathologial polymorphism for two uncharged polar amino acids, serine versus tyrosine, respectively. An MboI digest of the 511 bp exon 1 PCR product results in polymorphic 334-bp versus 247-bp and 87-bp fragments plus a constant 177-bp fragment (see figure).

Frequency: Estimated from 26 unrelated normal Caucasians of northern European ethnic origin.

A1 (334-bp fragment): 0.48

A2 (247-bp and 87-bp fragments): 0.52

All Chinese and Indian Asians exhibit only the 247-bp and 87-bp fragments in the small sample (5 individuals) analyzed.

Chromosomal Localization: The human tyrosinase gene has been mapped to chromosome $11 \mathrm{q} 14 \rightarrow 21$ (4).

Mendelian Inheritance: Autosomal codominant segregation was observed in two families.

Acknowledgements: Aided by grant AR39892 from the National Institutes of Health and Clinical Research Grant No. 6-408 from the March of Dimes Birth Defects Foundation.

References: 1) Kwon,B.S. et al. (1987) Proc. Natl. Acad. Sci. USA 84, 7473-7477. 2) Shibahara,S. et al. (1988) Tohuku J. Exp. Med. 156, 403-414. 3) Saiki,R.K. et al. (1988) Science 239, 487-491. 4) Barton,D. et al. (1988) Genomics 1, 17-24.

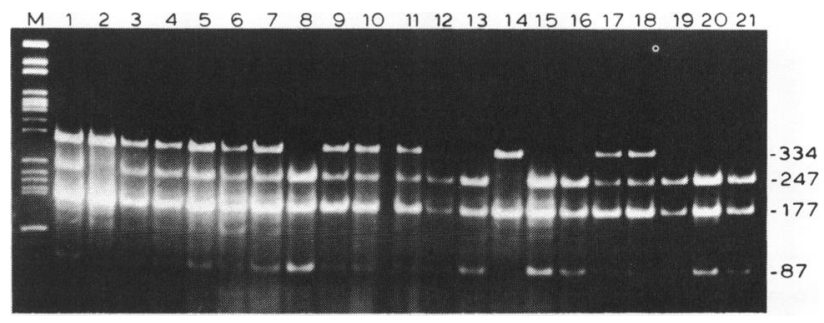

